\title{
MOTIVASI MASYARAKAT KOTA MAKASSAR MELAKUKAN TRANSAKSI MELALUI E-COMMERCE
}

\author{
Fatmawati
}

Prodi Ekonomi Syariah Universitas Islam Makassar

fatmawatiazfat@gmail.com

Received: 21 April 2020; Revised: 15 June 2020; Published: 19 June 2020

\begin{abstract}
ABSTRAK
Penelitian ini bertujuan untuk melihat motivasi masyarakat Makassar bertransaksi melalui e-commerce. Model transaksi yang terhitung baru dalam masyarakat, namun menjadi trend tersendiri dan begitu diminati hampir tiap kalangan dalam masyarakat. Penelitian ini merupakan field research jenis deskriptif kualitatif yang dilakukan di Makassar menggunakan pendekatan teologis normative, fenomenologi dan ekonomi Islam. Hasil penelitian ini menunjukkan bahwa motivasi transaksi melalui e-commerce terdiri dari motivasi rasional yaitu motivasi yang terjadi karena adanya pertimbangan secara matang dari konsumen sebelum memutuskan untuk bertransaksi dan motivasi emosional yaitu motivasi tranksaksi yang spontanitas muncul ketika melihat barang yang unik atau menarik, sama halnya dalam transaksi konvensional. Bedanya, dalam transaksi $e$ - commerce Masyarakat akan medapatkan value added atau nilai tambah berupa "excelent Services" atau pelayanan yang sangat baik karena berbagai kemudahan yang ada di e-commerce sehingga masyarakat akan merasa termanjakan dalam bertransaksi.
\end{abstract}

Kata Kunci: Motivasi; transaksi; e-commerce

\section{ABSTRACK}

This study aims to see the motivation of the Makassar people to transact through e-commerce. The transaction model is relatively new in society, but has become a trend of its own and is so desirable in almost every circle of society. This research is a descriptive qualitative field research conducted in Makassar using a normative theological, phenomenological and Islamic economic approach. The results of this study indicate that transaction motivation through E-commerce consists of rational motivation, that is motivation that occurs due to careful consideration of consumers before deciding to transact and emotional motivation, namely the spontaneous motivation to emerge when seeing unique or interesting items, as well as in conventional transactions. The difference is that in an e-commerce transaction, the community will get value added or added value in the form of "excellent services" or excellent services because of the various facilities available in e-commerce so that the community will feel pampered in the transaction.

Keyword: Motivation; transactions; E-Commerce. 


\section{PENDAHULUAN}

Pada tahun 1960, internet merupakan proyek Departemen Pertahanan Amerika yang diperuntukkan sebagai jaringan komunikasi yang terintegrasi dan saling menghubungkan antara komunitas sains dan militer yang dikenal dengan ARPANET( Advanced Research Projekt Agency Network). Kemudian pada tahun 1990, internet mulai diperkenalkan secara luas. Sejak saat itu internet mulai dikenal dan digeluti oleh masyarakat sehingga internet tidak lagi menjadi hal baru dan asing bagi masyarakat. Perkembangan pengguna jasa internet yang begitu pesat berpotensi akan terciptanya masyarakat modern. ${ }^{1}$

Internet banyak diadopsi oleh perusahaan dalam menjalankan kegiatan bisnis sejak internet digunakan secara komersial, seperti untuk proses pemasaran produk atau jasa perusahaan tersebut. Internet dapat dimanfaatkan sebagai media informasi yang paling efektif dalam memasarkan produk atau barang dan jasa yang dimiliki perusahaan kepada seluruh lapisan masyarakat secara langsung dalam waktu yang singkat. Melalui internet produsen dapat menemukan konsumen potensialnya dengan mudah dan cepat. Salah satu contoh hadirnya perusahaan dalam internet yakni hadirnya online store yang ada di e-commerce bahkan mewarnai hampir seluruh media sesial yang ada di Indonesia. Transaksi jual beli barang atau jasa dengan memanfaatkan jaringan internet disebut sebagai Electronic Commerce atau e-commerce. ${ }^{2}$

Hasil survei APJII (Asosiasi Penyelenggara Jasa internet Indonesia), mengemukakan bahwa pengguna internet di Indonesia pada tahun 2016 mencapai 132,7 juta jiwa, merupakan setengah dari jumlah penduduk Indonesia yaitu 256,2 juta jiwa. Diatara pengguna tersebut hanya beberapa orang yang tidak mengetahui bahwa internet digunakan sebagai media jual beli online. Sebesar 130,8 juta jiwa pengguna internet mengetahui bahwa internet dapat dimanfaatkan sebagai media jual beli produk dan yang pernah melakukan transaksi secara online berjumlah 84,2 juta jiwa. ${ }^{3}$ Hal tersebut menunjukkan

${ }^{1}$ Adi Purwanto, Analisis Kepercayaan Konsumen dalam Belanja Online di Bukalapak.com Menggunakan Teknology Acceptance Model (TAM) (Jurnal Ekonomika, Vol. 9 No. 1 Juni 2016), h. 14.

${ }^{2}$ Dwi Putra Jati Aribowo Pengaruh Trust Dan Perceived Of Risk Terhadap Niat Untuk Bertransaksi Menggunakan E-commerce, JURNAL NOMINAL / VOLUME II NOMOR I / TAHUN 2013( 9 agustus 2016)

${ }^{3}$ Asosiasi Penyelenggara Jasa Internet Indonesia(APJII), https://apjii.or.id/content/read/39/264/Survei-Internet-APJII-2016, Survei internet APJII 2016 ( Januari 2017). 
bahwa pertumbuhan e-commerce di negeri ini begitu pesat. Berdasarkan data dari e-Marketer bahwa transaksi e-commerce pada tahun 2014 mencapai angka RP 25,1 triliun, dan diperkirakan akan terus meningkat pada tahun 2016 ke level RP 69,8 triliun, dengan kurs rupiah pada angka Rp 13.200 per dollar Amerika. ${ }^{4}$

Makassar merupakan pasar potensial e-commerce di Indonesia. Berdasarkan data kementrian Komunikasi dan Informasi (Kominfo) bahwa pengguna aktif internet di Makassar pada tahun 2016, mencapai angka4 72.000 jiwa dari total 1,7 juta jiwa penduduk kota Makassar. Data tersebut tentu akan menjadi daya Tarik tersendiri bagi pelaku bisnis utamanya penggiat $e$-commerce. PT Astragraphi Xprints Indonesia (AXI), merupakan salah satu perusahaan yang melakukan ekspansi perusahaan ke Makassar dengan memperkenalkan produk axiqoe.com dan print dokumen berbasis online melalui Xprint Web services (XWS) yang memungkinkan pelanggan perusahaan melakukan print dokumen dimana saja tanpa harus ke perusahaan terkait. ${ }^{5}$

E-commerce dapat dikatakan masih sangat baru dalam kehidupan masyarakah jika dibandingkan dengan transaksi konvensional yang telah lama mandarah daging dalam masyarakat Indonesia khususnya masyarakat kota Makassar. Akan tetapi, kehadiran perdagangan digital ini berkembang dengan pesat, dan menjadi trend tersendiri. Masyarakat begitu tertarik dan berminat untuk melakukan transaksi melalui e-commerce baik melalui Tokopedia, shopee, Bukalapak, Lazada maupun e-commerce lainnya. Berdasarkan asumsi tersebut Peneliti tertarik untuk mengkaji lebih dalam mengenai motivasi masyarakat, khususnya masyarakat Kota Makassar untuk melakukan transaksi melalui ecommerce

\footnotetext{
${ }^{4}$ Databoks,https://databoks.katadata.co.id/datapublish/2016/11/16/transaksi-ecommerce-indonesia-naik-500-dalam-5-tahun, Transaksi E_commerce Indonesia Naik 500\% dalam 5 Tahun. (Januari 2017).

${ }^{5}$ Berita Kota Makassar, https://beritakotamakassar.fajar.co.id/berita/2016/09/30/axiperkenalkan-bisnis-e-commerce-dan-print-berbasis-online/ AXI Perkenalkan Bisnis E-commerce dan Print Berbasis Online, (22 Januari 2017).
} 


\section{TINJAUAN PUSTAKA}

\section{Motivasi}

Motivasi merupakan energi aktif yang menyebabkan terjadinya perubahan pada diri seseorang yang tanpak pada gejala kejiwaan, perasaan, dan juga emosi sehingga mendorong individu untuk bertindak atau melakukan sesuatu dikarenakan adanya tujuan, kebutuhan atau keinginan yang harus terpuaskan. ${ }^{6}$ Menurut Andrew Gustnest motivasi adalah keadaan yang mendorong individu mencapai tujuan tertentu. ${ }^{7}$ Dapat difahami bahwa motivasi adalah energi yang memberikan kekuatan kepada individu untuk melakukan suatu tindakan atau perbuatan tertentu untuk mencapai suatu tujuan yaitu kepuasan.

Nugroho J Setiadi ${ }^{8}$ dalam Yeti Nurhayati mengemukakan bahwa motivasi masyarakat atau konsumen dalam bertransaksi terbagi atas motivasi yang didahului oleh beberapa pertimbangan sebelum memutuskan membeli barang atau jasa dan motivasi bertransaksi tanpa ada pertimbangan matang sebelum memutuskan membeli barang dan jasa. Motivasi transaksi konsumen dengan beberapa pertimbangan yang mendahuluinya dikategorikan sebagai motivasi rasional dan motivasi transaksi konsumen tanpa ada pertimbangan yang mendahului mengenai danpak jangka panjang dari pembelian tersebut dikategorikan sebagai motivasi emosional.

Abraham Maslow membagi motivasi individu atau motif perilaku manusia dalam memenuhi kebutuhannya menjadi lima tingkatan kebutuhan yang harus dipenuhi secara berjenjang, yaitu kebutuhan fisik sebagai kebutuhan primer, kebutuhan keamanan, kebutuhan sosial, kebutuhan penghargaan, dan kebutuhan aktualisasi diri. ${ }^{9}$ Kelima tingkat kebutuhan tersebut diuraikan oleh

${ }^{6}$ Abdul Majid. Strategi pembelajaran, (Bandung: PT.Remaja Rosdakarya. 2013), h.308.

${ }^{7}$ Andrew Gustnest Binalay, Silvya L. Mandey,Christoffel M. O. Mintardjo, Pengaruh Sikap, Norma Subjektif dan Motivasi Terhadap Minat Beli Secara Online Pada Mahasiswa Fakultas ekonomi dan Bisnis di Manado, Jurnal EMBA,Vol.4 No.1 Maret 2016, h. 395-406

${ }^{8}$ Nugroho J Setiadi, Perilaku Konsumen Perspektif Kontemporer Pada Motif, Tujuan, dan Keinginan Konsumen, (Jakarta : Cetakan Keenam. Prenadamedia Group, 2015), h.35 dalam Yeti Nurhayati, Pengaruh Rational Buying Motive dan Emosional Buying Motive Terhadap Repurchase Intention, (Jurnal Ekonologi, Volume 4, Nomor 1, 2017), h.221-224

${ }^{9}$ Eka Suhartini, Motivasi, kepuasan Kerja dan Kinerja (Cet.1; Makassar: Alauddin University Press, 2013), h. 39. 
Hamner dan Organ dalam Tri Anjarwati: 2015 sebagai berikut:10 1) Kebutuhan Fisiologis yaitu kebutuhan fisik yang harus dipenuhi oleh manusia seperti makan dan minum serta memiliki tempat tinggal. 2) Kebutuhan Rasa aman, seperti aman dari bahaya, aman dari ancaman orang lain. 3) Kebutuhan Sosial, kebutuhan untuk diterima dalam masyarakat, bersahabat dan berorganisasi. 4) Kebutuhan harga diri, yaitu kebutuhan untuk berprestasi, memiliki mobil mewah, rumah mewah dan sebagainya. 5) Kebutuhan Aktualisasi Diri atau pencapaian tertinggi yang bisa didapatkan oleh manusia seperti jabatan strategis.

E-commerce mulai dikenal pada tahun 1990 melalui adanya inisiatif untuk mengubah paradigma transaksi jual beli dari cara konvensional ke dalam bentuk digital elektronik berbasiskan komputer dan jaringan internet. ${ }^{11}$.Electronic Commerce merupakan konsep baru yang bisa digambarkan sebagai proses jual beli barang atau jasa pada World Wide Web Internet atau proses jual beli atau pertukaran produk, jasa dan informasi melalui internet. Seperti halnya jual beli konvensional, jual beli digital juga melibatkan berbagai pihak dalam bertransaksi, meskipun dalam jual beli secara digital pihak-pihak yang bertransaksi tidak bertemu secara langsung satu sama lain atau tidak ada kegiatan tatap muka, tetapi mereka dihubungkan melalui internet. ${ }^{12}$

Misbahuddin ${ }^{13}$ menjelaskan bahwa meskipun terdapat beberapa defenisi yang berbeda mengenai $e$-commerce, tetap terdapat kesamaan yang dapat terlihat dalam tiga hal yaitu bahwa transaksi dalam e-commerce terjadi dari dua pihak yang sama-sama bertransasksi, kemudian terdapat produk atau jasa yang ditransaksikan dan Internet sebahai media yang digunakan dalam transaksi tersebut

E-commerce difahami sebagai bentuk perdagangan digital atau transaksi jual beli produk baik barang maupun jasa pada Word Wide Web yang dapat diakses melalui komputer atau android yang terkoneksi dengan jaringan

${ }^{10}$ Tri anjarwati, Motivasi dari Sudut Pandang Teori Hirarki Kebutuhan Maslow, Teori Dua Faktor Herzberg, Teori X Y Mc Gregor, dan Teori Motivasi Prestasi Mc Clelland, (Jurnal Ilmu Ekonomi \& Manajemen April 2015, Vol. 1 No.1. hal. 45 - 54.

11I Putu Agus Eka Pratama, E-commerce. E-Bisnis dan Mobile Commerce BerbasiskanOpen Source, (Bandung: Informatika, 2015), h.2

12Azhar Muttaqin, Transaksi E-commerce dalam Tinjauan Hukum Jual beli Islam, (ULUMUDDIN, Volume VI, Tahun IV, Januari - Juni 2010), h. 459-467)

${ }^{13}$ Misbahuddin, E-commerce dan Hukum Islam, (Makassar: Alauddin Universitas Press, 2012), h. 158 
internet. Karakter e-commerce yaitu perdagangan digital yang dilakukan pada Word Wide Web seperti www Lazada.com, www Tokopedia.com, www shopee.com. Juga dapat dilakukan dengan langsung membuka aplikasi yang telah pasang di android masing-masing. Berbeda dengan jual beli online yang biasanya dilakukan langsung pada akun sosial seseorang seperti facebook, Instagram maupun whatsapp.

\section{Metodologi Penelitian}

Penelitian ini merupakan penelitian kualitatif dengan field research yang dilaksanakan di Kecamatan Tamalate, Rappocini, Pannakkukang, Bontoala dan Biringkanaya kota Makassar. Pemilihan kelima kecamatan tersebut dilakukan secara insidental atau tidak terencana sebelumnya, akan tetapi informan yang berhasil ditemukan oleh Peneliti pada umumnya berasal dari kelima kecamatan tersebut. Pemilihan Kota Makassar sebagai tempat penelitian ini adalah karena Kota Makassar merupakan salah satu Kota Metropolitan, yang memiliki masyarakat yang melek tekhnologi. Masyarakat Kota Makassar pada umumnya terbiasa melakukan interaksi dengan internet, mulai dari keperluan mencari data atau berbagai informasi, membuka media sosial sampai pada kebiasaan melakukan belanja online. Penelitian ini menggunakan pendekatan teologis normatif, fenomonologi dan pendekatan ekonomi islam. Data primer diperoleh dari seller atau pelapak dan buyer atau pembeli di e-commerce, dan data sekunder diperoleh dari berbagai literatur yang memiliki relevansi dengan penelitian ini. Pengumpulan data diperoleh melalui proses wawancara dengan responden, melakukan observasi langsung dan dokumentasi. Data yang terkumpul kemudian dianalisis melalui reduksi data, penyajian data sampai pada tahap penarikan kesimpulan. 


\section{HASIL DAN PEMBAHASAN}

Secara umum penelitian ini dilakukan di Makassar, dengan melakukan interview mendalam terhadap masyarakat yang menggunakan jasa salah satu $e-$ commerce. Makassar merupakan kota metropolitan dengan luas areal mencapai 175,79 km2 dengan jumlah penduduk sebesar 1. 112.688 juta jiwa. Luas tersebut menjadikan Makassar sebagai wilayah terbesar di Indonesia Timur sekaligus menjadi kota terbesar keempat di Indonesia. ${ }^{14}$

\section{Motivasi Masyarakat Kota Makassar Melakukan Transaksi Melalui E- commerce}

Motivasi dapat difahami sebagai dorongan dari dalam diri seseorang untuk melakukan sesuatu karena adanya kebutuhan untuk segera dipenuhi untuk mencapai kepuasan. Aktivitas atau kegiatan tersebut memberikan kepuasan dalam memenuhi kebutuhan, maka aktivitas tersebut cenderung diulang kembali. Adanya E-commerce individu dapat memenuhi segala kebutuhannya tanpa harus menghabiskan waktu mengunjungi beberapa swalayan atau supermarket. Berikut adalah motivasi Masyarakat Kota Makassar melakukan transaksi melalu e-commerce

Hadirnyan e-commerce memberikan berbagai kemudahan transaksi seperti kemudahan dalam pembayaran karena adanya system Cash On Delivery(COD) atau metode pembayaran yang dilakukan setelah barang diterima oleh pembeli. Kemudahan dalam mengakses barang-barang yang belum tersedia di toko-toko offline dan kemudahan dalam mendapatkan produk-produk luar Negeri. Transaksi lintas negara dapat dilakukan dengan mudah. Begitu besar manfaat yang dirasakan oleh masyarakat dengan adanya e-commerce. Hasil pemikiran manusia dengan menghadirkan teknologi mampu memberikan kontribusi fenomenal dalam kehidupan manusia. Semakin canggihnya perkembangan teknologi seolah menghilangkan batas, jarak dan waktu. Melakukan komunikasi, transaksi lintas negara dapat dilakukan dengan mudahnya tanpa membutuhkan biaya. Perkembangan teknologi membawa dampak yang begitu besar dalam sendi-sendi kehidupan tidak terkecuali dalam kehidupan ekonomi. Adanya $e-$ commerce produk-produk luar negeri yang biasanya hanya bisa dinikmati oleh kalangan tertentu menjadi lebih muda diperoleh oleh berbagai kalangan. Adanya jual beli online barang-barang yang sebelumnya jauh, berada di luar

\footnotetext{
14Pemerintah Kota Geografis Kota Makassar, https://makassarkota.go.id/geografis/\# (3 Februari 2017).
} 
negeri tidak bisa terjamah, menjadi bisa dijangkau tanpa harus keluar rumah. ${ }^{15}$ Hal yang sebelumnya sepertinya mustahil didapatkan, akhirnya jadi mudah. Seperti halnya untuk barang-barang luar negeri sebelum adanya jual beli online, hanya orang tertentu saja yang bisa membelinya. Sekarang di lazada kita dapat membeli barang-barang luar negeri dengan mudah dan murah dan kualitasnya sangat bagus. ${ }^{16}$ Pembelian melalui e-commerce seperti tokopedia maupun lazada karena barang-barang yang dibutuhkan belum tersedia di Toko-Toko di Makassar, misalnya butuh alat-alat komputer tetapi setelah dicari dibeberapa toko ternyata belum tersedia, akhirnya dicari melalui e-commerce dan produk yang diinginkan tersedia, ditambah lagi dengan adanya pembayaran COD semakin memudahkan dalam transaksi. ${ }^{17}$ Sesuai dengan teori kebutuhan Maslow, bahwa motivasi individu dalam melakukan suatu tindakan adalah karena adanya kebutuhan fisik, dan pada tingkatan motivasi yang tertinggi yaitu adanya motivasi untuk aktualisasi diri, masyarakat juga ingin mendapatkan nilai tambah dalam berbelanja melalui e-commerce berupa adanya kemudahan dalam memperoleh kebutuhan, hal ini sebagai salah satu manipestasi dari adanya keinginan individu untuk mengaktualisasikan dirinya.

Efisiensi waktu. Bagi masyarakat pekerja yang memiliki kesibukan yang padat tentu saja tidak memiliki waktu yang cukup untuk berbelanja ke mallmall atau pasar offline, tentu saja dengan kehadiran e-commerce menjadi sebuah solusi bagi mereka yang sibuk bekerja. Hadirnya e-commerce di tengah-tengah masyarakat membawa angin segar bagi semua kalangan terutama bagi masyarakat yang memiliki kesibukan di tempat kerja. Berbelanja melalui salah satu e-commerce dianggap lebih mudah dan praktis. Ketika membutuhkan sesuatu, langsung cek-cek melalui toko online, pilih barang, transfer kemudian menunggu pesanan datang. Dibandingkan harus berbelanja ke Mall atau ke pasar tradisional yang membutuhkan waktu yang lebih lama. ${ }^{18}$

Harga bersaing. Harga yang ditawarkan pada e-commerce cenderung lebih murah dan sangat bersaing. Salah satu motivasi berbelanja di toko online seperti Lazada dan tokopedia adalah karena harganya bersaing, harga yang ditawarkan

\footnotetext{
15Meyrda Syahrani (31), Kec.Bontoala, Wawancara, 29 Desember 2016.

16Amrin (35), Kec. Panakkukang, Wawancara , 24 Desember 2016.

17Hasrul (30), Kec. Rappocini, Wawancara , 24 Desember 2016

${ }^{18}$ Nur Fitriyah Halim (31), Kec. Tamalate, Wawancara, 30 Desember 2016
} 
pada toko online cenderung lebih murah dibandingkan dengan di toko offline. ${ }^{19}$ Abdul Rahman, salah seorang karyawan BUMN di Kota Makassar juga menyatakan bahwa Selama ini lebih sering berbelanja di toko online yang memiliki situs resmi dibandingkan dengan yang di media sosial seperti facebook, maupun BBM. Berbelanja melaui e-commerce seperti di Lazada, Tokopedia, elevenia, sophee dan sebagainya memberikan rasa aman, nyaman dan kemudahan dibandingkan berbelaja langsung karena bisa dilakukan kapan saja, dimana saja, sehingga dapat memilih produk yang diinginkan dengan cepat, dan harga sangat bersaing. ${ }^{20}$

Promo dan diskon. Adanya promo seperti potongan harga untuk pembelian produk tertentu, atau promo gratis ongkos kirim dan diskon barangbarang tertentu menjadi motivasi yang sangat berpengaruh. Melalui e-commerce Masyarakat bisa dengan mudah mengetahui jika lagi ada promo. Misalnya dalam rangka ulang tahun Lazada, atau ulang tahun shopee, maka disitu banyak promo yang ditawarkan yang otomatis menjadi kesempatan emas untuk berbelanja. Selain itu di Lazada misalnya, pada saat diskon memang barangnya diskon tidak seperti di mall-mall, harga barangnya di up terlebih dahulu sebelum didiskon. ${ }^{21}$

Perasaan aman. Masyarakat merasa lebih aman karena tidak harus meninggalkan tempat untuk bertransaksi sehingga tidak khawatir kemungkinan adanya pencopet atau begal seperti ketika berbelanja secara offline. Belanja ke pasar tradisional atau mall membutuhkan biaya lebih banyak dan juga perasaan was-was karena adanya begal maupun pencopet. Oleh karena itu berbelanja melalui internet lebih praktis dan murah, hanya mengandalkan handphone dan jempol. ${ }^{22}$ Motivasi emosional, yaitu dorongan seketika untuk berbelanja hanya karena faktor godaan mata ketika melihat produk-produk yang menarik dan unik. Berbeda dengan beberapa pernyataan di atas tentang motivasi dalam melakukan transaksi melalui e-commerce, Muthmainnah Rafiuddin, seorang Pegawai Negeri Sipil mengatakan bahwa terkadang melakukan pembelian melalui e-commerce hanya karena godaan mata. Begitu membuka aplikasi belanja online seperti Lazada ataupun shopee dan melihat barang-barang yang lucu atau menarik langsung tertarik untuk membelinya. Meskipun pada dasarnya

\footnotetext{
${ }^{19}$ Asnur Indraman(24), Kec.Panakkukang, Wawancara, 24 Desember 2016

${ }^{20}$ Abdul Rahman (31), Kec.Panakkukang, Wawancara, 24 Desember 2016

${ }^{21}$ Asnur Indraman(24), Kec.Panakkukang, Wawancara, 24 Desember 2016

${ }^{22 N u r}$ Fitriyah Halim (31), Kec. Tamalate, Wawancara, 30 Desember 2016
} 
terkadang barang yang dipesan tersebut tidak dibutuhkan hanya disimpan sebagai barang koleksi. ${ }^{23}$ Hal tersebut menunjukkan bahwa salah satu dorongan seseorang dalam berbelanja dalam e-commerce adalah karena pengaruh melihat barang-barang yang menarik, sehingga seketika berkeinginan untuk memiliki barang tersebut, meskipun pada dasarnya barang tersebut tidak betul-betul dibutuhkan. Hal ini sebagaimana dikemukan Nugroho bahwa salah satu motivasi membeli konsumen adalah motivasi emosional, yakni konsumen terkesan terburu-buru membeli produk yang dilihat tanpa pertimbangan panjang mengenai efek dari keputusan tersebut. Teori tersebut sejalan dengan hasil penelitian Yeti Nurhayati ${ }^{24}$ bahwa emotional buying motive (motif pembelian emosional) memiliki pengaruh yang kuat dan positif terhadap repurchase intention (minat beli ulang). Oleh karena itu meskipun transaksi yang dilakukan hanya karena motivasi emosional atau hanya karena dorongan sesaat yang menyebabkan sesorang bertransaksi, hal tersebut tidak akan menjadikan seseorang untuk tidak bertransaksi lagi dilain waktu atau bertransasksi ulang.

\section{KESIMPULAN}

Motivasi Masyarakat melakukan transaksi melalui e-commerce terdiri atas motivasi rasional dan motivasi emosional. Motivasi rasional didasari oleh beberapa pertimbangan sebelum bertransaksi seperti adanya kemudahan dalam pembayaran karena adanya system Cash On Delivery(COD), kemudahan dalam mengakses barang-barang yang belum tersedia di toko-toko offline dan kemudahan dalam mendapatkan produk-produk luar Negeri, efisiensi waktu, harga bersaing, adanya Promo dan diskon yang ditawarkan dan perasaan aman dalam bertransaksi karena tidak harus meninggalkan tempat untuk bertransaksi sehingga tidak khawatir kemungkinan adanya pencopet atau begal seperti ketika berbelanja secara offline. Motivasi emosional, yaitu dorongan seketika untuk berbelanja hanya karena faktor godaan mata ketika melihat produk-produk yang menarik. transaksi e-commerce masyarakat bisa mendapatakan nilai tambah berupa excellent services karena berbagai kemudahan yang terdapat dalam Ecommerce yang tidak didapatkan dalam transaksi konvensional.

\footnotetext{
${ }^{23}$ Muthmainnah Rafiuddin (30), Kec.Rappocini, Wawancara, 29 Desember 2016

${ }^{24}$ Yeti Nurhayati, Pengaruh Rational Buying Motive dan Emosional Buying Motive Terhadap Repurchase Intention, (Jurnal Ekonologi, Volume 4, Nomor 1, 2017), h.221-224
} 


\section{DAFTAR PUSTAKA}

Anjarwati, Tri. (2015). Motivasi dari Sudut Pandang Teori Hirarki Kebutuhan Maslow, Teori Dua Faktor Herzberg, Teori X Y Mc Gregor, dan Teori Motivasi Prestasi Mc Clelland, Jurnal Ilmu Ekonomi \& Manajemen, Vol. 1 No.1. hal. 45 - 54 .

Aribowo, Dwi Putra Jati (2013). Pengaruh Trust Dan Perceived Of Risk Terhadap Niat Untuk Bertransaksi Menggunakan E-commerce, Jurnal Nominal , Volume II Nomor I .

Asosiasi Penyelenggara Jasa Internet Indonesia.(2016). Survei internet APJII 2016 https:/ / apjii.or.id/content/read/39/264/Survei-Internet-APJII-2016, (20Januari 2017).

Binalay, Andrew Gustnest, Silvya L. Mandey,Christoffel M. O. Mintardjo. (2016). Pengaruh Sikap, Norma Subjektif dan Motivasi Terhadap Minat Beli Secara Online Pada Mahasiswa Fakultas ekonomi dan Bisnis di Manado, Jurnal EMBA, Vol.4 No.1, h. 395-406.

Clifford T. Morgan. (1961). Introduction to Psychology, New York: The Mc Graw Hill Book Company.

Databoks,

https:/ / databoks.katadata.co.id/datapublish/2016/11/16/transaksi-e-

commerce-indonesia-naik-500-dalam-5-tahun , Transaksi E_commerce Indonesia Naik 500\% dalam 5 Tahun. (Januari 2017).

Ernie Tisnawati Sule dan Kurniawan Saefullah. (2008). Pengantar Manajemen, Ed.I; Jakarta: Kencana Prenadamedia Group.

Gemala Dewi Dkk. (2013). Hukum Perikatan Islam di Indonesia ,Jakarta: kencana Prenada Media Grup.

Majid, Abdul. (2013). Strategi pembelajaran, Bandung: PT.Remaja Rosdakarya.

Misbahuddin. (2012). E-commerce dan Hukum Islam, Makassar: Alauddin Universitas Press.

M. Ngalim Purwanto (1996). Psikologi Pendidikan, Bandung: Remaja Rosdakarya.

Muttaqin, Azhar. (2010). Transaksi E-commerce dalam Tinjauan Hukum Jual beli Islam, Jurnal Ulumuddin, Volume VI, Tahun IV, h. 459-467.

Nurhayati, Yeti. (2017). Pengaruh Rational Buying Motive dan Emosional Buying MotiveTerhadap Repurchase Intention, Jurnal Ekonologi, Volume 4, Nomor 1, h.221-224.

Pemerintah Kota Makassar (2017). Geografis Kota Makassar. https://makassarkota.go.id/geografis/\# (3 Februari 2017).

Purwanto, Adi. (2016). Analisis Kepercayaan Konsumen dalam Belanja Online di Bukalapak.com Menggunakan Teknology Acceptance Model (TAM), Jurnal Ekonomika, Vol.9

Pratama, I Putu Agus Eka. (2015). E-commerce. E-Bisnis dan Mobile Commerce Berbasiskan Open Source, Bandung: Informatika. 
Fatmawati,: Motivation; transactions; E-Commerce.

Setiadi, J Nugroho. 2015. Perilaku Konsumen Perspektif Kontemporer Pada Motif, Tujuan, dan Keinginan Konsumen. Jakarta : Cetakan Keenam. Prenadamedia Group.

Suhartini, Eka. (2013). Motivasi, kepuasan Kerja dan Kinerja, Cet.1; Makassar: Alauddin University Press. 